Preventive Veterinary Medicine Received on: 05/08/2021

Accepted on: 16/01/2022

\title{
Singeing to improve visual aspect and microbiological quality of pig carcasses
}

\author{
Chamuscamento para melhora do aspecto visual e a qualidade microbiológica de \\ carcaças de suínos
}

${ }^{1}$ VIVAN, Gabriela Farinon

https://orcid.org/0000-0001-7199-4004
${ }^{1}$ BADARO, Andrea Catia Leal https://orcid.org/0000-0002-7235-6597

${ }^{2}$ HASHIMOTO, Elisabete Hiromi https://orcid.org/0000-0002-1368-4785

${ }^{1}$ Universidade Tecnológica Federal do Paraná. Câmpus Francisco Beltrão. Departamento Acadêmico de Ciências Agrárias. Linha Santa Bárbara, s/n, PR, CEP:85601-970. Francisco Beltrão -PR. Brasil.

${ }^{2}$ Universidade Tecnológica Federal do Paraná. Câmpus Ponta Grossa. R. Doutor Washington Subtil Chueire, 330 - Jardim Carvalho, CEP: 84017-220 Ponta Grossa - PR,. Brasil

*Mail for correspondence: elisabete@utfpr.edu.br

\section{ABSTRACT}

The proper operating conditions of the singeing machine on pig slaughterhouses to achieve good carcass quality are little reported. Thus, this study aimed to evaluate the effect of an automatic singeing machine on the quality of pig carcasses for better control in pork production. A two-factor (pressure and time) completely randomized design was used. The carcasses were subjected to four treatments using gas pressures of 0.6 and 0.8 kgf.cm ${ }^{-2}$ for 3.7 and 4.2 seconds of exposure to the flame. The carcasses were analyzed as for visual appearance, counts of Enterobacteriaceae and Escherichia coli, and temperature. Gas consumption was also assessed during the process. Carcasses subjected to $0.6 \mathrm{kgf} . \mathrm{cm}^{-2}$ for $4.2 \mathrm{~s}$ had a better visual appearance. Both pressure and time reduced the counts of Enterobacteriaceae and E. coli. Regarding gas consumption, exposure to the flame for $4.2 \mathrm{~s}$ consumed three times more gas than exposure for $3.7 \mathrm{~s}$. Among the treatments tested, singeing using a pressure of $0.6 \mathrm{kgf}_{\mathrm{cm}}{ }^{-2}$ for $4.2 \mathrm{~s}$ was sufficient to reduce microbial counts and improve visual appearance. This singeing standardization serves as a reference for slaughterhouses to produce pork with a visual appearance of better acceptability by consumers.

Keywords: Slaughter. Escherichia coli. Enterobacteriaceae. Singeing. Gas.

\section{RESUMO}

As condições adequadas de operação do chamuscador para contribuir com o aspecto visual e qualidade microbiológica são pouco relatadas. O objetivo deste estudo foi avaliar o efeito do chamuscador automático na qualidade das carcaças, visando melhor controle na produção de carne suína. $\mathrm{O}$ delineamento experimental adotado foi inteiramente casualizado com dois fatores (pressão e tempo). As carcaças suínas foram submetidas a 
quatro tratamentos com 0,6 e 0,8 kgf.cm² de pressão de gás e 3,7 e 4,2 segundos de exposição à chama. As carcaças foram analisadas quanto ao aspecto visual, contagem de Enterobacteriaceae e Escherichia coli e temperatura. Além disso, o consumo de gás foi avaliado na operação. As carcaças submetidas a $0,6 \mathrm{kgf.cm}^{-2}$ por 4,2 s apresentaram melhores resultados de aspecto visual. Em geral, tanto a pressão quanto o tempo reduziram a contagem de Enterobacteriaceae e E. coli. Quanto ao consumo de gás, o tempo de 4,2 s apresentou um gasto 3 vezes maior que o tempo de $3,7 \mathrm{~s}$. Entre os tratamentos testados, o chamuscamento com pressão de $0,6 \mathrm{kgf}^{\mathrm{cm}} \mathrm{cm}^{-2}$ e tempo de $4,2 \mathrm{~s}$ apresentou-se suficiente para redução das contagens microbiana e melhor aspecto visual. A padronização desta etapa de chamuscamento serve de referência para matadouros a fim de produzir carne suína com aspecto visual de melhor aceitabilidade pelo mercado consumidor.

Palavras-chave: Abate. Escherichia coli. Enterobacteriaceae. Chamuscamento. Gás.

\section{INTRODUCTION}

Pork is one of the main protein sources consumed and available worldwide. Brazil is the third-largest producer and exporter of pork in the world (USDA, 2020). Intervention strategies to reduce the counts or eliminate quality indicator and pathogenic microorganisms are essential for the food industry. The processing industry seeks to ensure the quality required by the commercial standard of products, while also meeting the restrictive sanitary requirements of the importing market, and thus standing out economically.

In Brazil and Europe, the application of dry heat for decontamination is permitted, such as the singeing in the dirty zone of pig slaughtering. Singeing is performed during dehairing, complementing the process of removing hair from swine carcasses (Brasil, 1995). Although bacterial decontamination is not the main function of singeing, the heat released by the flame results in high temperatures on the carcass surface and contributes to reducing the microbial load (Loretz et al., 2011). However, there are few studies on the singeing effect on decontamination and the visual appearance of carcasses.
Meat cuts influenced by the singeing flame have become valued in the market; also, pork consumption continues to increase in the world. From 2007 to 2015, the national consumption per capita increased by $16.16 \%$, showing a slight decrease in 2016 and 2017, which was justified by the increase in exports, which account for $18.5 \%$ of Brazilian production (ABPA, 2018). In this scenario, requirements related to the commercial standard of products are of great economic importance.

The decontamination effectiveness using a singeing machine depends on the process parameters, such as exposure time (Loretz et al., 2011) and operating gas pressure. Pathogenic microorganisms are sensitive to high temperatures, so the higher the carcass surface temperature, increased by using a singeing machine, the greater the possibility of decontamination. However, an intense flame can result in visually burned carcasses, with low commercial acceptance, whereas a weak flame results in reddish products.

Due to the energy demand in this stage, singeing operating standardization should consider the control of gas volume used in the process, aiming at economic and environmental gains. 
Therefore, this study aimed to evaluate the singeing operating conditions to obtain pig carcasses with commercially acceptable visual appearance and reduced counts of indicator microorganisms.

\section{Material and Methods}

\section{Experimental design}

A completely randomized design was used, considering two factors (gas pressure and exposure time to the singeing flame), each one with two levels. Each treatment consisted of a binomial - exposure time and singeing gas pressure - which were determined based on the minimum and maximum operating conditions of the singeing machine in the study slaughterhouse. Thus, the equipment capacity and the flame intensity and color were considered for determining the pressures. To determine the times, the visual appearance of the carcasses (inefficient and intense) was considered. Therefore, four treatments were analyzed, as follow: $\mathrm{T} 1=0.6 \mathrm{kgf} . \mathrm{cm}^{-2}$ for $3.7 \mathrm{~s}, \mathrm{~T} 2=0.6 \mathrm{kgf} . \mathrm{cm}^{-2}$ for $4.2 \mathrm{~s}, \mathrm{~T} 3$ $=0.8 \mathrm{kgf} . \mathrm{cm}^{-2}$ for $3.7 \mathrm{~s}$, and $\mathrm{T} 4=0.8$ kgf.cm ${ }^{-2}$ for $4.2 \mathrm{~s}$.

\section{Pig carcasses}

This study was carried out in a slaughterhouse, in southern Brazil, with a slaughter capacity of 230 pigs per hour, operating under a Federal Inspection system and a Hazard Analysis and Critical Control Points system (Brasil, 2003). The batches consisted of Duroc $x$ Landrace crossbred pigs, acquired from pig farms with a maximum capacity of 1000 animals, with a mean weight of 125 $\pm 8 \mathrm{~kg}$ and a mean age of 128 days. The batches used for microbiological analysis were slaughtered before operational hygiene, aiming at performing the experiment under a higher microbial load condition. An adapted automatic singeing machine $\left(\right.$ Sulmaq $\left.^{\circledR}\right)$ was used, operating with LPG (liquefied petroleum gas), 38 burner nozzles reaching the entire carcass at an ideal distance for the flame length, burning time and gas pressure adjustable operating conditions, and air pressure of $7.0 \mathrm{kgf.cm}{ }^{-2}$, with an approximate capacity of 400 pigs per hour.

\section{Visual appearance analysis of pig carcasses after singeing}

The visual appearance analysis was performed in 90 pig carcasses, in slaughtering process, before and after singeing, for each treatment. Superficial burns of any size at any area of the carcasses (indicative of intense or concentrated singeing) were considered, as well as reddish appearance (indicative of inefficient singeing). Carcasses with a visual appearance intermediate to these two patterns were considered as acceptable and were counted to make a comparison between treatments.

\section{Microbiological analysis}

Samples from each treatment (T1, T2, $\mathrm{T} 3$, and T4) were collected in three replications, on alternate days. For each treatment, collections were made from five random carcasses, every day before singeing, and from the same five carcasses after singeing, collecting 40 samples per day, totaling 120 samples. The number of samples was based on previous studies involving pig slaughter (Pearce et al., 2004) and on collection history at the singeing stage in the slaughterhouse. Also, pig batches were selected within an integrated production system and were thus under similar 
treatment conditions because, in this system, the animals and their feed come from the same source and the baches are subjected to standardized management (ABCS, 2014).

The samples were collected in accordance with Circular No. 130/2007/CGPE/DIPOA (Brasil, 2007), following a non-destructive method, using a disposable abrasive sponge, previously hydrated with $10 \mathrm{~mL}$ buffered peptone water $\left(3 \mathrm{M}^{\mathrm{TM}}\right)$, and a $10 \times 10 \mathrm{~cm}$ stainless steel delimiter, previously sterilized. The sponges were aseptically applied on a sampling area of $100 \mathrm{~cm}^{2}$, in four areas of each carcass (leg, loin, belly, and jowl), totaling $400 \mathrm{~cm}^{2}$ of collected area. This procedure was performed in the same carcasses in the two collection periods (before and after singeing).

Enterobacteria and Escherichia coli counts were performed on Petrifilm plates $\quad\left(3 \mathrm{M}^{\mathrm{TM}} \quad\right.$ Petrifilm $\left.^{\mathrm{TM}}\right)$ for Enterobacteriaceae (EB) counts and $E$. coli/coliform (EC) counts, respectively (AOAC, 2016a; AOAC, 2016b).

\section{Carcass temperature determination after singeing}

The carcass temperature was recorded 12 seconds after applying the flame. This time was sufficient so that the carcass went through the singeing machine and the temperature was not influenced by the flame applied to the next carcass. The temperature was measured using a thermographic camera (Thermal Imager FLUKE-TI25), which can measure from -20 to $+350{ }^{\circ} \mathrm{C}\left(-4{ }^{\circ} \mathrm{F}\right.$ to $\left.+662{ }^{\circ} \mathrm{F}\right)$, with an accuracy of $\pm 2{ }^{\circ} \mathrm{C}$.

For temperature analysis, thermal images of five carcasses were obtained for each treatment, for 15 minutes. Afterward, the measurements were made and the data were analyzed by the line profile method, using the Fluke SmartView ${ }^{\circledR}$ software. This method was described by Le Roux et al. (2015) and consists of drawing a line between the ends of the carcass (from the leg to the jowl). The line generated by the software (Fluke SmartView ${ }^{\circledR}$ ) in the FLUKETI25 Thermal Imager showed the temperature gradient.

\section{Singeing gas consumption}

The energy expenditure of each treatment was calculated based on the variation in the gas volume in the tank of the supply center, which varies according to the time the gas is released to be consumed in the singeing, regarding the total number of singed carcasses. The result showed a gas consumption in grams per singed pig.

\section{Statistical analysis}

The data from the analyses of quality indicator microorganisms and carcass temperatures were subjected to analysis of variance, followed by the Tukey test, for comparing the means at a significance level of $5 \%(\mathrm{p}<0.05)$, using the STATISTICA $^{\circledR}$ software, version 12.0 (Statsoft Inc., USA) . The qualitative data from the visual appearance analysis of the carcasses and the gas consumption were expressed descriptively and as a percentage of the frequency of defects and conformities observed.

\section{RESULTS AND DISCUSSION}

For visual appearance analysis, images of the carcasses were recorded after singeing for comparing each treatment (T1, T2, T3, and T4). Representative images of each treatment are shown in Figure 1. 

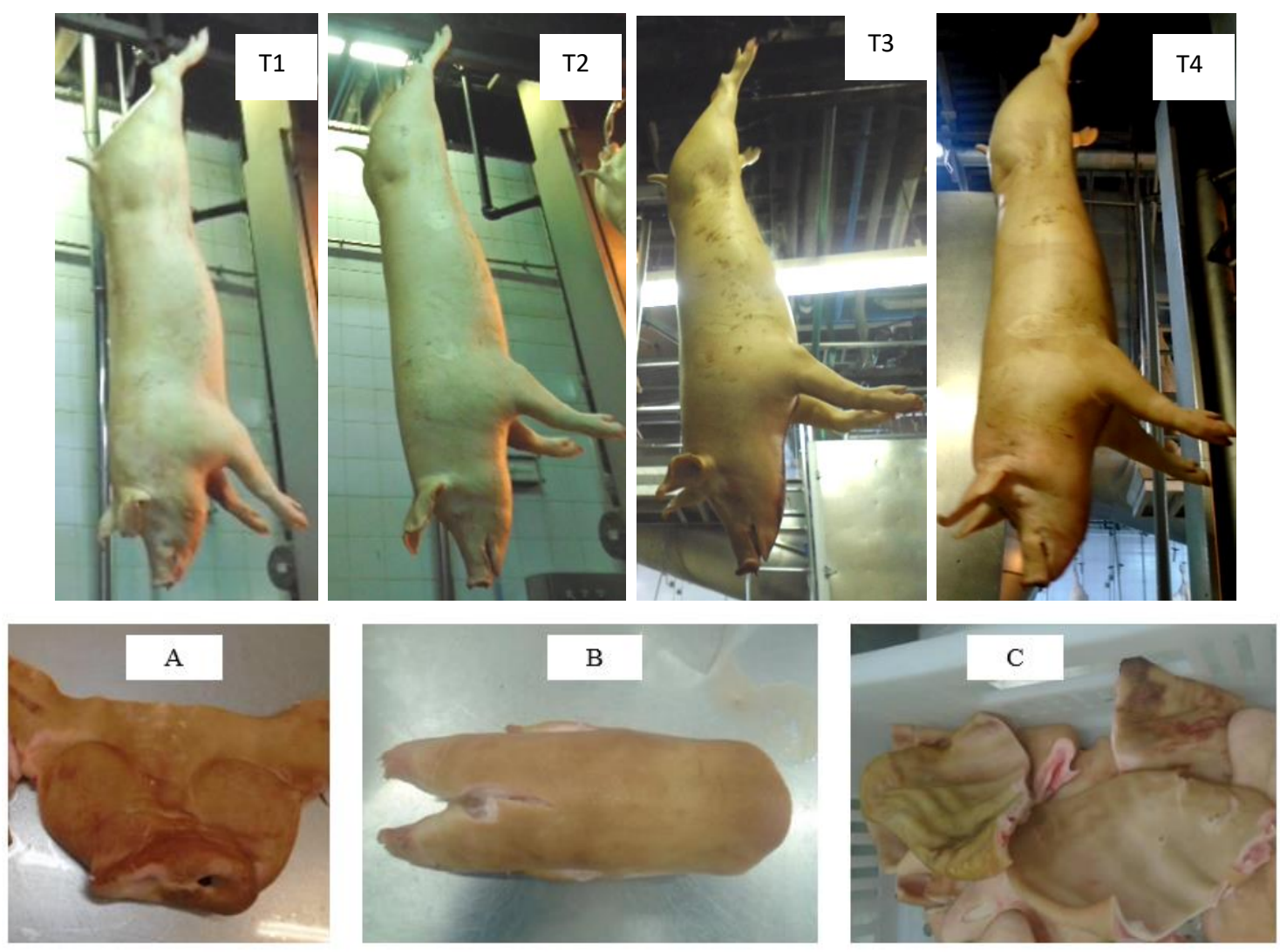

Figure 1 - Visual appearance of pig carcasses after singeing. T1 $\left(0.6 \mathrm{kgf.cm}{ }^{-2} / 3.7 \mathrm{~s}\right), \mathrm{T} 2(0.6$ kgf.cm $-2 / 4.2 \mathrm{~s})$, T3 $(0.8 \mathrm{kgf.cm}-2 / 3.7 \mathrm{~s})$, and T4 $\left(0.8 \mathrm{kgf.cm}^{-2} / 4.2 \mathrm{~s}\right)$; and visual appearance snout (A), foot (B) and ears (C) after singeing.

Considering the scarcity of information in the literature on visual changes in carcasses caused by singeing, a visual appearance analysis was performed. This analysis is necessary because of the sensory characteristics required for the product commercialization.

The carcasses subjected to the gas flame for $3.7 \mathrm{~s}$ (T1 and T3) stood out since their ends such as the head (ear and snout) and the feet, which are the most critical regions in terms of contact with the flame, became reddish (Figure 1). A different result was observed when the flame was applied for $4.2 \mathrm{~s}$ (T2 and T4), in which the color of the carcasses' ends ranged from white to dark, resulting in some corrugated ears (Figure 1).

Regarding the pressures, T3 and T4 (0.8 $\mathrm{kgf.} . \mathrm{cm}^{-2}$ ) resulted in carcasses with more intense dark color and some situated burns. Also, the temperature in the area near the singeing machine led to a sensory perception of a higher heat release, due to the increased pressure, when compared to the pressure of 0.6 $\mathrm{kgf.} \mathrm{cm}^{-2}$. The same was observed when the time was increased from 3.7 to $4.2 \mathrm{~s}$. For each treatment, 90 carcasses were analyzed, which showed different visual appearances, as shown in Figure 2. 


$$
100
$$

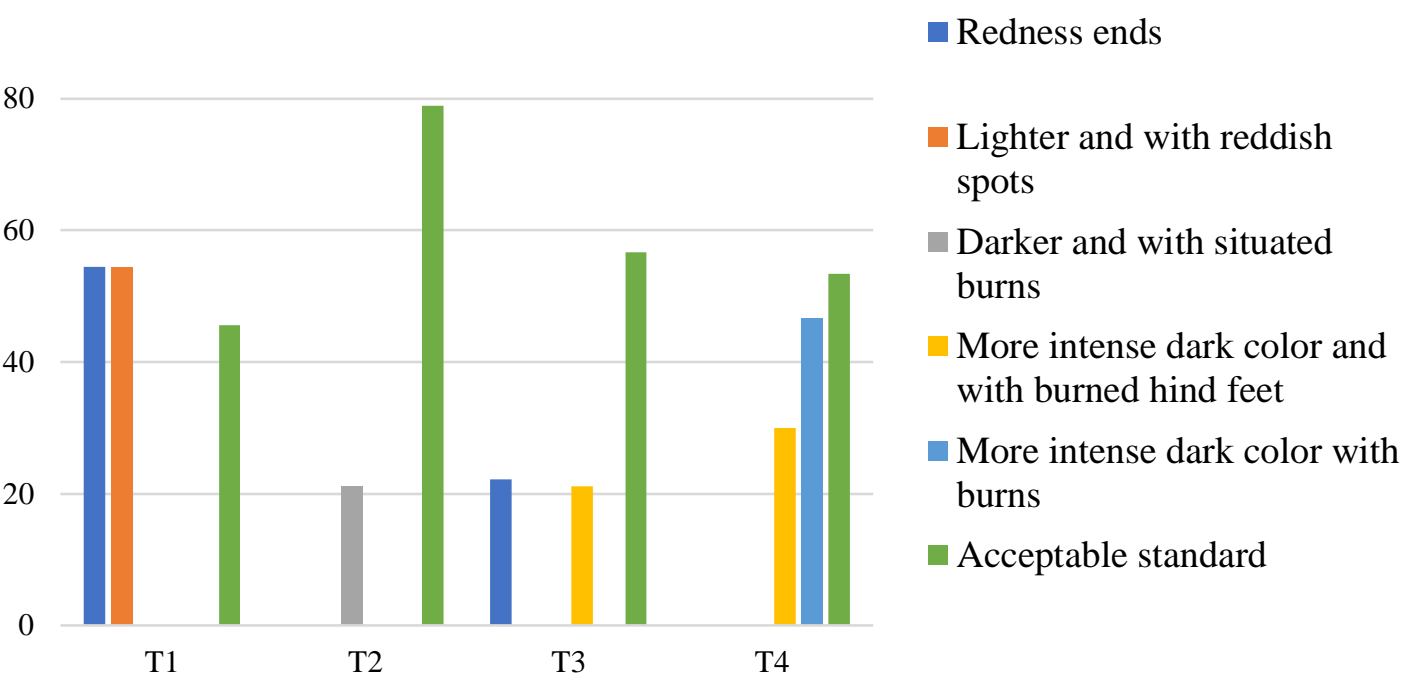

Figure 2. Percentage of samples per treatment, with an acceptable visual appearance. T1 $(0.6$ kgf.cm ${ }^{-2}$ for $\left.3.7 \mathrm{~s}\right)$, T2 $\left(0.6 \mathrm{kgf.cm}{ }^{-2}\right.$ for $\left.4.2 \mathrm{~s}\right), \mathrm{T} 3\left(0.8 \mathrm{kgf} \mathrm{cm}^{-2}\right.$ for $\left.3.7 \mathrm{~s}\right)$, and T4 $(0.8$ kgf.cm ${ }^{-2}$ for $\left.4.2 \mathrm{~s}\right)$. N per treatment $=90$.

As for the acceptable visual appearance, T2 had the best result $(78.88 \%)$, followed by T3 (56.66\%), T4 (53.33\%), and T1 $(45.55 \%)$. In T4 (higher pressure and longer time), among the $42(46.66 \%)$ carcasses with more intense dark color and burns, $27(30 \%)$ had burned hind feet. In T1 (lower pressure and shorter time), the $49(54.45 \%)$ carcasses with reddish ends also had a lighter color and reddish spots. T2 resulted in 19 (21.12\%) carcasses with a darker color and some situated burns. Regarding T3, 20 (22.22\%) carcasses had reddish ends, and $19(21.11 \%)$ carcasses had a more intense dark color and burned hind feet.
Naturally, carcasses have different visual appearances according to their genetic variability. The analyzed batches consisted of duroc $\times$ landrace crossbred pigs, which have golden red and pink fur, respectively, and may have dark spots (abcs, 2014). Thus, the carcasses need to be analyzed before and after singeing, as some aspects can be derived from the carcass characteristics and others from the singeing.

During singeing, we detected several factors that can affect the visual appearance of the carcasses. To establish a reference for pork processing industries, these factors were compiled and shown in chart 1 . 
Chart 1. Factors that affect the visual appearance of pig carcasses during singeing.

\begin{tabular}{|l|l|}
\hline $\begin{array}{l}\text { Factors that affect the visual } \\
\text { appearance of pig carcasses }\end{array}$ & $\begin{array}{l}\text { Main characteristics of pig carcasses after } \\
\text { singeing }\end{array}$ \\
\hline 1. Carcass size. & $\begin{array}{l}\text { Larger carcasses: Tendency to have situated } \\
\text { burns on the body of the carcass and inefficient } \\
\text { singeing on the extremities. } \\
\text { Smaller carcasses: Tendency to have } \\
\text { inefficient singeing on the snout and darker } \\
\text { ends. }\end{array}$ \\
\hline $\begin{array}{l}\text { 2. Carcass position at the time of gas } \\
\text { activation. }\end{array}$ & $\begin{array}{l}\text { Burned or reddish areas due to irregular flame } \\
\text { distribution. }\end{array}$ \\
\hline $\begin{array}{l}\text { 3. Spots and scratches on the skin } \\
\text { caused by previous steps. }\end{array}$ & $\begin{array}{l}\text { Dark color and burnt appearance in the } \\
\text { affected areas. }\end{array}$ \\
\hline 4. Position of the burner nozzles. & $\begin{array}{l}\text { Misdirected nozzles can cause situated burns } \\
\text { or reddish spots. }\end{array}$ \\
\hline 5. Gas quality & $\begin{array}{l}\text { Gas composition and precautions in the } \\
\text { operations until its use are directly related to } \\
\text { the flame quality (intensity, color, and } \\
\text { temperature) and, consequently, to the } \\
\text { singeing efficiency. }\end{array}$ \\
\hline
\end{tabular}

The carcasses differ in weight and size, which interferes with their exposure to the flame. Larger carcasses remain closer to the burner nozzles and may suffer situated burns, in addition to having less contact with the flames directed towards the pork butt and front foot. Smaller carcasses tend to have less contact with the central nozzle flame, which is directed towards the snout.

When the flame reaches the pork butt and the front foot for a longer time, these regions contract due to the heat, which can result in dark feet. Under this same condition, with a longer exposure time to the flame, the ear becomes dark and corrugated. On the other hand, a shorter exposure time to the flame can cause redness in the feet.

The visual appearance of pork has a great commercial impact. Brazilian consumers demand lighter pork products.
Therefore, as pork tends to oxidize over time, even though they are properly packaged and stored. The meat cuts are subjected to a bleaching process, using chemical products, and later salting to prevent the oxidation process (Simitzis et al., 2009). And thus be sold as a salty product or in packages as ingredients for "feijoada". When the cut becomes reddish or dark after singeing, the bleaching is influenced, as it does not achieve a desirable white color, affecting the commercialization of the product.

On the other hand, foreign consumers demand products in natura, i.e., the cuts should not be bleached, which requires greater care with their visual appearance and criticality in their selection, as red or dark feet have lower acceptance by the importing market.

The burner nozzles are adjusted to provide a homogeneous singeing 
throughout the carcass, according to the position in which the carcasses enter the singeing machine to be exposed to the gas flame. When the carcasses enter the machine swing or in back position, singeing is affected and, in this case, the flame distribution becomes irregular, which may result in reddish and/or burned areas.

The carcass skin may also have spots and/or scratches, caused by previous steps such as scalding and dehairing. After singeing, these regions acquire a dark color and a burnt appearance. These characteristics are different from those resulting from the intensity or direction of the flame, which causes yellowish or dark brown burns.

When the carcass skin rapidly dehydrates, due to burning or excessive heat, its use by customers who produce fried derivatives is hindered, as this anomaly forms white spots on the final product. Moreover, if the time or temperature is excessive, the collagen fibers may disintegrate, impacting the quality of food produced by those who use skin for gelatin production (Molander, 1986).

Variations in the gas composition can generate different Reid vapor pressure (RVP), which represents the ease of gas condensation at a given temperature, and result in gas with different weathering, which represents the ease of gas vaporization at atmospheric pressure. The LPG composition includes a variable proportion of propane/propene and butane/butene and its specification and classification are established by ANP Resolution No. 18, of September 2, 2004. Liquefied petroleum gases are composed of hydrocarbon mixtures with chemical predominance, resulting in LPG with varied compositions, even within a standard specification. In addition to chemical compositions, other precautions are necessary for the commercialization of quality LPG, which are related to transport, storage, and use operations (Petrobrás, 2018).

Given the above, gas composition and operating precautions until its use are directly related to the quality of the flame to be generated from gas combustion, interfering with the flame intensity, color, and temperature, consequently influencing the singeing efficiency.

Special attention should be paid to the cuts that showed greater variability in visual appearance. Although they have already been considered of lower value, the growing demand and preference of importing countries, such as China, have added value to these cuts (IATP, 2014; USDA, 2020). The average monthly volume of such small edible parts (foot, ear, and tail), exported to China by the slaughterhouse in which this study was conducted, is 111,000 units per month, which is an expressive value of great economic impact. At a global level, Brazilian exports of these small pork cuts represent $10.81 \%$ of exported products, behind the other cuts, which account for $83.63 \%$ of exported products (ABPA, 2018).

Considering the variability in the system functioning, T2 promoted a better visual appearance, more homogeneous, and had the lowest variation regarding the patterns established by consumers and customers. It is noteworthy that, according to the current legislation, there are no visual standards established for the analyzed products, since Regulation No. 711/1995 classifies singeing only as a supplement for hair removal ${ }^{(2)}$. Thus, the evaluation of factors that interfere with this step and the process improvement can provide the final product with higher commercial value. 
The counts of Enterobacteriaceae and $E$. coli, before and after singeing, and the percentage of microbial reduction in pig carcasses after singeing are shown in Table 1.

Table 1. Enterobacteriaceae and Escherichia coli counts, before and after singeing, and percentage of microbial reduction in pig carcasses after singeing.

\begin{tabular}{|c|c|c|c|c|c|c|}
\hline \multirow[t]{3}{*}{ Treatment } & \multicolumn{3}{|c|}{ Enterobacteriaceae } & \multicolumn{3}{|c|}{ Escherichia coli } \\
\hline & \multicolumn{2}{|c|}{$\begin{array}{l}\text { Mean } \pm \text { SD } \\
\left(\text { UFC. } \mathrm{cm}^{-2}\right)\end{array}$} & \multirow{2}{*}{$\begin{array}{c}\% \\
\text { reduction }\end{array}$} & \multicolumn{2}{|c|}{$\begin{array}{l}\text { Mean } \pm \text { SD } \\
\left(\text { UFC. }^{\left.-c^{-2}\right)}\right.\end{array}$} & \multirow{2}{*}{$\begin{array}{c}\% \\
\text { reduction }\end{array}$} \\
\hline & Before & After & & Before & After & \\
\hline $\mathrm{T} 1$ & $\begin{array}{l}1.1063^{\mathrm{Aa}} \\
+03096\end{array}$ & $\begin{array}{l}0.0083^{\mathrm{Ab}} \\
+00095\end{array}$ & $80^{\mathrm{A}}$ & $\begin{array}{l}0.3727^{\mathrm{Aa}} \\
+02804\end{array}$ & $\begin{array}{l}0.0021^{\mathrm{Aa}} \\
+00036\end{array}$ & $93.33^{\mathrm{A}}$ \\
\hline $\mathrm{T} 2$ & $\begin{array}{l}1.1354^{\mathrm{Aa}} \\
\pm 0.5948\end{array}$ & $\begin{array}{l}0.0333^{\mathrm{Ab}} \\
\pm 0.0577\end{array}$ & $93.33^{\mathrm{A}}$ & $\begin{array}{l}0.3042^{\mathrm{Aa}} \\
\pm 0.1751\end{array}$ & $\begin{array}{l}0.0042^{\mathrm{Ab}} \\
\pm 0.0072\end{array}$ & $93.33^{\mathrm{A}}$ \\
\hline $\mathrm{T} 3$ & $\begin{array}{l}0.6125^{\mathrm{Aa}} \\
\pm 0.3023\end{array}$ & $\begin{array}{l}0.0062^{\mathrm{Ab}} \\
\pm 0.0108\end{array}$ & $93.33^{\mathrm{A}}$ & $\begin{array}{c}0.2646^{\mathrm{Aa}_{ \pm}} \\
0.2707\end{array}$ & $\mathrm{Nd}^{\mathrm{Aa}}$ & $100^{\mathrm{A}}$ \\
\hline $\mathrm{T} 4$ & $\begin{array}{l}1.1542^{\mathrm{Aa}} \\
\pm 0.7313\end{array}$ & $\begin{array}{l}0.0042^{\mathrm{Aa}} \\
\pm 0.0072\end{array}$ & $93.33^{\mathrm{A}}$ & $\begin{array}{l}0.3000^{\mathrm{Aa}} \\
\pm 0.0797\end{array}$ & $\mathrm{Nd}^{\mathrm{Ab}}$ & $100^{\mathrm{A}}$ \\
\hline
\end{tabular}

Nd.: <0,0625 UFC.cm ${ }^{-2}$ Treatments: T1 $(0.6$ kgf.cm²/3.7 s); T2 $(0.6$ kgf.cm-2/4.2 s); T3 (0.8 kgf.cm $2 / 3.7 \mathrm{~s})$ e T4 $(0.8 \mathrm{kgf.cm}-2 / 4.2 \mathrm{~s})$.

*averages indicated by the same letter do not differ statistically, uppercase in the column and lowercase in the line, by the Tukey test at the level of $5 \%$ of significance.

The main source of microbial contamination of carcasses is of fecal origin; therefore, counts of indicator microorganisms such as Escherichia coli and Enterobacteriaceae is the most suitable method to assess the hygienic condition in the slaughter process (Barco et al., 2015). After singeing, the carcasses showed a significant reduction in Enterobacteriaceae counts, except for $\mathrm{T} 4$, in which a high initial count in a single sample directly interfered with the comparison. Regarding E. coli counts, only $\mathrm{T} 2$ and $\mathrm{T} 4(4.2 \mathrm{~s})$ showed a difference $(p<0.05)$, before and after singeing.

There was no difference between $\mathrm{T} 1, \mathrm{~T} 2$, $\mathrm{T} 3$, and T4 regarding the counts of Enterobacteriaceae and E. coli, before and after singeing. It is noteworthy that the binomials were determined taking into account the singeing limitations concerning the conditions applicable to the slaughterhouse, as a pressure lower than $0.6 \mathrm{kgf} . \mathrm{cm}^{-2}$ and a time less than 3.7 $\mathrm{s}$ affected the flame quality, resulting in an inefficient singeing, as well as a pressure higher than $0.8 \mathrm{kgf} . \mathrm{cm}^{-2}$ and a time greater than $4.2 \mathrm{~s}$ were a bit excessive. For both limitations, the visual quality of the products was considered given their commercialization and acceptance in the market.

The treatments resulted in a decrease greater than $93.33 \%$ of Enterobacteriaceae, except for $\mathrm{T} 1$ (shorter time and lower pressure), which caused a decrease of $80 \%$. T3 and T4 (pressure of $0.8 \mathrm{kgf.cm}{ }^{-2}$ ) and T1 and T2 (pressure of $0.6 \mathrm{kgf}_{\mathrm{cm}} \mathrm{cm}^{-2}$ ) reduced E. coli counts by $100 \%$ and $93.33 \%$, respectively.

A study carried out in pig slaughterhouses in the United Kingdom made it possible to estimate a singeing 
mean time of $7.61 \mathrm{~s}$, ranging from 0-20 s. The authors also observed that the increased singeing time resulted in a lower probability of carcasses positive for Salmonella spp. (Marier et al., 2014). Because of the direct contact with the flames, the carcasses are exposed to high temperatures, which leads to a rapid microbial elimination or reduction. The effectiveness of bacterial reductions in pig carcasses after singeing has been reported in several studies and, for Enterobacteriaceae, these reductions were mainly in the range of 1.8-2.8 UFC $\log$ (Yu et al., 1990; Rahkio et al., 1992; Bolton et al., 2002; Pearce et al., 2004; Spescha et al., 2006; Le Roux et al., 2015) . Regarding Salmonella sp., Yu et al. (1999), through the singeing process, found a reduction from $7-0 \%$ in the incidence of this pathogen.

Ghafir et al. (2008) observed that pig carcass samples positive for Salmonella spp. also had higher levels of E. coli and Enterobacteriaceae, indicating a correlation between the levels of these indicators and the prevalence of Salmonella spp., which is one of the main enterobacteria related to public health (EFSA, 2012).

Alban and Stärk (2005) developed a risk model to simulate the prevalence of Salmonella spp. during pork production, from the producer until the carcass in the slaughterhouse, and concluded that singeing is the only process in pig slaughtering able to eliminate contamination by Salmonella spp.

After being subjected to singeing, the carcass goes through the polishing step, and the surviving bacteria may be mechanically spread by scrapers, which can be difficult to access, impairing the hygienization (Borch et al., 1996). In this case, an alternative would be performing two singeing steps: one after the first polishing, after dehairing, and another after the second polishing ( $\mathrm{Yu}$ et al., 1999).

From the slaughter clean zone, no step makes it possible to reduce the carcasses contamination, consequently, the subsequent steps increase the contamination (Delhalle et al., 2008, Busser et al., 2011). Therefore, the lower the microbial counts after singeing, the lower the probability of crosscontamination between the equipment and other carcasses in the next stages of the process, evidencing the importance of this stage from a microbiological point of view.

The temperature gradient method used for measuring the temperature of the carcasses made it possible to calculate the minimum, intermediate and maximum temperatures for each treatment (Table 2).

Table 2. Mean temperatures of pig carcasses after singeing.

\begin{tabular}{cccc}
\hline \multirow{2}{*}{ Treatment } & \multicolumn{3}{c}{ Temperature \pm SD $\left({ }^{\circ} \mathrm{C}\right)$} \\
\cline { 2 - 4 } & Minimum & Intermediate & Maximum \\
\hline T1 & $53.90^{\mathrm{d}} \pm 0.55$ & $57.51^{\mathrm{d}} \pm 0.25$ & $61.00^{\mathrm{d}} \pm 0.69$ \\
T2 & $56.31^{\mathrm{c}} \pm 0.18$ & $60.21^{\mathrm{c}} \pm 0.29$ & $64.94^{\mathrm{c}} \pm 0.56$ \\
T3 & $58.94^{\mathrm{b}} \pm 0.37$ & $65.16^{\mathrm{b}} \pm 0.18$ & $71.35^{\mathrm{b}} \pm 0.38$ \\
T4 & $60.75^{\mathrm{a}} \pm 0.39$ & $67.96^{\mathrm{a}} \pm 0.18$ & $75.36^{\mathrm{a}} \pm 0.32$ \\
\hline
\end{tabular}

Treatments: T1 $\left(0.6\right.$ kgf.cm $2 / 3.7$ s); T2 $\left(0.6 \mathrm{kgf.cm}^{-2} / 4.2 \mathrm{~s}\right) ; \mathrm{T} 3\left(0.8 \mathrm{kgf.cm}^{-2} / 3.7 \mathrm{~s}\right)$ e T4 $(0.8$ kgf.cm-2/4.2 s).

*averages indicated by the same letter do not differ statistically by the Tukey test at the level of $5 \%$ of significance. 
In all treatments. the highest temperatures were recorded in the upper part of the carcass (leg). as the heat tends to rise. differently from the lower part (jowl). which had the lowest temperatures. Intermediate temperatures were recorded in the area (belly and loin) between these two parts. Temperature ranges were recorded in the carcasses. as follows: 53.90-60.75 ${ }^{\circ} \mathrm{C}$ (minimum). 57.51-67.96 ${ }^{\circ} \mathrm{C}$ (intermediate). and 61$75.36{ }^{\circ} \mathrm{C}$ (maximum). for $\mathrm{T} 1$ and $\mathrm{T} 4$. respectively. Temperature differences between $\mathrm{T} 4$ and $\mathrm{T} 1$ were $6.85{ }^{\circ} \mathrm{C}$ (minimum). $10.45^{\circ} \mathrm{C}$ (intermediate). and $14.36{ }^{\circ} \mathrm{C}$ (maximum) (Table 2).

The thermometer used in this study had maximum limit of $370^{\circ} \mathrm{C}$. According to Kich and Souza (2015). the singeing temperature to which the carcasses are exposed can exceed $700{ }^{\circ} \mathrm{C}$. In all treatments. the thermometer recorded flame temperatures above this limit. LPG can reach high temperatures. as it has a high calorific value. which provides the flame with a high heat capacity (Petrobras, 2018); however. considering the thermal treatment for microbial inactivation. the temperature reached by the carcasses is a more appropriate reference standard to assess differences between the analyzed treatments. as the variation found in this study is because of the flame exposure time and gas pressure.

By adjusting the burner. it was possible to obtain time and pressure variations of

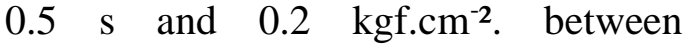
treatments. Time and pressure variations directly influenced the temperature of the carcasses during singeing. There was a significant $(\mathrm{p}<0.05)$ increase in the minimum. intermediate. and maximum temperatures of the carcasses when the singeing time and pressure were increased.

Considering that the carcasses before singeing were at $32{ }^{\circ} \mathrm{C}$. the treatments reached increases in the intermediate temperature of $25.51{ }^{\circ} \mathrm{C}$ (T1). $28.21{ }^{\circ} \mathrm{C}$ (T2). $33.16{ }^{\circ} \mathrm{C}$ (T3). and $35.96{ }^{\circ} \mathrm{C}$ (T4). in a short period (3.7 and $4.2 \mathrm{~s}$ ). In this condition. there is a lower probability for the development of thermo-resistant microorganisms because the bacteria are exposed to a high temperature for a few seconds. The condition of becoming thermo-resistant is due to a longer exposure time (Humphrey, 1981, PeñaMeléndez et al., 2014).

In the case of an insufficient temperature. there is an incomplete inactivation of microorganisms. which can recover and subsequently proliferate (Turner, 2002). The presence of cold areas during singeing influences the survival of bacteria on the carcass surface. Thereby. the remaining bacteria can cause a redistribution of contamination in the next stage (polishing). Considering the low initial microbial load (Table 1). the temperatures reached by the carcasses were sufficient to eliminate Enterobacteriaceae and E. coli.

Borch et al. (1996) state that during singeing pig carcass surface can reach $100{ }^{\circ} \mathrm{C}$ in a few seconds. There was a significant increase in the temperature of the carcasses when pressure and time were increased. which affected the visual appearance. resulting in darker and burned carcasses. Although higher temperature treatments cause greater microbial inactivation. the visual appearance should also be considered because it is an important commercial characteristic. 
The variation in costs $(\mathrm{R} \$)$ and gas consumption resulting from the exposure time to the flame during the singeing of pig carcasses are shown in Table 3. A mean of 3.170 slaughtered pigs per day was estimated for the slaughterhouse in which this study was conducted. considering the slaughter capacity and working hours per day.

Table 3. Gas consumption in relation to the analyzed time of singeing.

\begin{tabular}{|c|c|c|c|c|}
\hline \multirow[b]{3}{*}{ Time (s) } & \multicolumn{4}{|c|}{ Gas consumption } \\
\hline & \multicolumn{2}{|c|}{ Value for each carcass } & \multicolumn{2}{|c|}{ estimated value per day* } \\
\hline & $(\mathrm{g})$ & $(\mathrm{R} \$)$ & (g) & $(\mathrm{R} \$)$ \\
\hline 3.7 & 545 & 1.853 & $1,727.65$ & $5,874.01$ \\
\hline 4.2 & 565 & 1.921 & $1,791.05$ & $6,089.82$ \\
\hline
\end{tabular}

Singeing gas consumption in grams. per carcass. was converted to reais according to the LPG mean value over 12 months ( $\mathrm{R} \$ 3.40 / \mathrm{kg}$ of gas). In addition to the calculation by the gas volume variation. theoretical calculations were simulated to identify possible variations in the gas flow resulting from pressure oscillation. However. because LPG is a compressible gas. the pressure variation in the treatments $\left(0.2 \mathrm{kgf} . \mathrm{cm}^{-2}\right)$ caused no variations in the flow; therefore. the consumption variation due to the pressure oscillation could not be measured. This was only possible by considering the time.

Currently. the slaughterhouse in question has a monthly consumption indicator of $550 \mathrm{~g}$ of LPG/pig. operating at a pressure of $0.6 \mathrm{kgf.cm} \mathrm{cm}^{-2}$ and a time of $4.0 \mathrm{~s}$. For T1 and T3 (3.7 s). gas consumption was approximately $0.909 \%$ lower than the usual consumption. Applying these treatments. the company will save $\mathrm{R} \$ 0.017$ per pig and $\mathrm{R} \$ 53.89$ daily. On the other hand. T2 and T4 (4.2 s) consumed approximately $2.727 \%$ gas more than the usual procedure. If the company uses these treatments. it will have an increase of $\mathrm{R} \$ 0.051$ per pig and $\mathrm{R} \$ 161.67$ daily.
It should be considered that. in the visual appearance analysis. it was observed a prevalence of redness in the ends of the carcasses subjected to 3.7-second singeing (Chart 1); therefore. they did not meet the foreign market commercial standard and were thus destined for the internal market. Because of this. there is a decrease in the net margin of $25 \%$ for ear products and $53 \%$ for foot products. for example.

Some slaughterhouses in Denmark reduced the burner power to reduce energy consumption. estimating a cost of US $\$ 0.07$ per pig to increase efficiency. making a relatively low investment. in addition to helping to reduce the prevalence of Salmonella spp. (Alban \& Stärk, 2005).

\section{CONCLUSION}

Pig carcasses subjected to singeing at a pressure of $0.6 \mathrm{kgf} . \mathrm{cm}^{-2}$ for $4.2 \mathrm{~s}$ showed a good visual appearance and this condition was sufficient to reduce Enterobacteriaceae and Escherichia coli counts. T2 consumed more gas than T1 $\left(\begin{array}{ll}3.7 & \mathrm{~s}\end{array}\right)$ This consumption is compensated by the commercial gain from the improvement of the sanitary 
quality demanded by the importing market. Although singeing mainly aims to complement the hair removal in the dehairing process. the standardization of this step can represent sanitary and commercial gains. The standardization of singeing contributes to less gas consumption. providing economic and environmental gains. Several aspects relating to singeing were analyzed in our research; thus. we hope this information can be used as a support for the production of quality and safety pork by the industries.

\section{Acknowledgments}

This work has been supported by CAPES and UTFPR.

\section{REFERENCES}

ABCS. Associação Brasileira de Criadores de Suínos. Coordenação Técnica da Integral Soluções em Produção Animal. Produção de suínos: Teoria e prática. Brasília, DF.2014; 908p.

ABPA. Associação Brasileira de Proteína Animal. Relatório Anual 2018. São Paulo, SP. Availabe from: http://abpa-br.org/wpcontent/uploads/2018/10/relatorioanual-2018.pdf. 2018.

Alban, L, Stärk, K. D. C. (2005). Where should the effort be put to reduce the Salmonella prevalence in the slaughtered swine carcass effectively. Preventive Veterinary Medicine. 2005; 68:63-79. DOI:10.1016/j.prevetmed.2005.01.001.

AOAC Association of Official Analytical Chemists. Official Method 998.08 Confirmed Escherichia coli
Counts in Poultry, Meats and Seafood Dry Rehydratable Film Method (Petrifilm $^{\mathrm{TM}}$ E. coli/ Coliform Count Plate). 2016. 20 ed.

AOAC. Association of Official Analytical Chemists. Official Method 991.14. Coliform and Escherichia coli Counts in Foods Dry Rehydratable Film (Petrifilm $^{\mathrm{TM}}$ E. coli/ Coliform Count Plate and Petrifilm ${ }^{\mathrm{TM}}$ Coliform Count Plate) Methods. 2016. 20 ed.

Barco, L, Belluco, S, Roccato, A, Ricci, A. (2015). A systematic review of studies on Escherichia coli and Enterobacteriaceae on beef carcasses at the slaughterhouse. International Journal of Food Microbiology. 2015; 207:30-39.

DOI:10.1016/j.ijfoodmicro.2015.04.027

Bolton, DJ, Pearce, RA, Sheridan, JJ, Blair, IS, Mcdowell, DA, Harrington, D. Washing and chilling as critical control points in pork slaughter hazard analysis and critical control point (HACCP) systems. Journal of Applied Microbiology. 2002; 92:893-902. DOI:10.1046/j.13652672.2002.01599.x.

Borch, E, Nesbakken T, Christensen, H. Hazard identification in swine slaughter with respect to foodborne bacteria. International Journal Food Microbiology. 1996; 30:9-25. DOI:10.1016/0168-1605(96)00988-9.

Brasil . Ministério da Agricultura, Pecuária e Abastecimento. Circular Nº130 de 13 de fevereiro de 2007. Exportações de Carne Suína para os Estados-Membros da União Europeia. Brasília, DF, 2007; 10p. 
Brasil. Ministério da Agricultura, Pecuária e Abastecimento. Instrução Normativa $n^{\circ} 62$, de 26 de agosto de 2003. Métodos Analíticos Oficiais para Análises Microbiológicas para Controle de Produtos de Origem Animal e Água. Diário Oficial da União. 2003 set 18; Seção 1. Portuguese.

Brasil. Ministério da Agricultura, Pecuária e Abastecimento. Portaria $\mathrm{n}^{\circ}$ 711, de 01 de novembro de 1995. Aprovar as normas técnicas de instalações e equipamentos para abate e industrialização de suínos. Diário Oficial da União. 1995 nov 01; Seção 1. Portuguese.

Busser, EV, Maes, D, Houf, K, Dewulf, J, Imberechts, H, Bertrand, S, Zutter, L. Detection and characterization of Salmonella in lairage, on pig carcasses and intestines in five slaughterhouses. International Journal of Food Microbiology.2011;145:279-286.

DOI:10.1016/j.ijfoodmicro.2011.01.009

Delhalle, L, De Sadeleer, L, Bollaerts, K, Farnir, F, Saegerman, C, Korsak, N, Daube, G. Risk Factors for Salmonella and Hygiene Indicators in the 10 Largest Belgian Pig Slaughterhouses. Journal Food Protection, 2008; 71:1320-1329. DOI:10.4315/0362-028x-71.7.1320.

EFSA. European Food Safety Authority. Scientific opinion on an estimation of the public health impact of setting a new target for the reduction of Salmonella in turkeys. EFSA Journal, 13 abril 2012. Available from: https://efsa.onlinelibrary.wiley.com/doi/ epdf/10.2903/j.efsa.2012.2616.

Ghafir, Y, China, B, Dierick, K, Zutter, L, Daube, G. (2008). Hygiene Indicator
Microorganisms for Selected Pathogens on Beef, Pork, and Poultry Meats in Belgium. Journal of Food Protection. 2008; 71(1):35-45. DOI:10.4315/0362028x-71.1.35.

Humphrey, TJ. The Effects of $\mathrm{pH}$ and Levels of Organic Matter on the Death Rates of Salmonellas in Chicken Scaldtank Water. Journal of Applied Bacteriology, 1981; 51: 27-39. DOI:10.1111/j.1365-

2672.1981.tb00905.x.

IATP. Institute for Agriculture Trade Policy. China's Pork Miracle? Agribusiness and Development in China's Pork Industry. Global Meat Complex: The China Series.2014.

Kich, JD, Souza, JCPVB. Salmonella na suinocultura brasileira: do problema ao controle (1 ed). Brasília, DF: Embrapa 2015; 186p.

Le Roux, A, Lhommeau, T, Péran, T, Monziol, M, Minvielle, B. Decontamination on pork carcasses: qualification of thermic treatment by thermal image. Safepork 2015 Conference: Meat Inspection, quality, hygiene, safety and preservation. IFIP - French institute for pig and pork industry La Motte au Vicomte, France, 2015: 75-79.

Loretz, M, Stephan, R, Zweifel, C. Antibacterial activity of decontamination treatments for pig carcasses. Food Control, 2011; 22: 1121-1125.

DOI:10.1016/j.foodcont.2011.01.013.

Marier, EA, Snow, LC, Floyd, T, Mclaren, IM, Bianchini, J, Cook, AJC, Davies, RH. Abattoir based survey of 
Salmonella in finishing pigs in the United Kingdom 2006-2007. Preventive Veterinary Medicine, 2014; 117: 542553.

DOI:10.1016/j.prevetmed.2014.09.004.

Molander, E. Effect of singeing on the texture and histological appearance of pig skin. Meat Science, 1986; 16: 225235. DOI:10.1016/0309-

1740(86)90028-8

Pearce, RA, Bolton, DJ, Sheridan, DA, Mcdowell, DA, Blair, IS, Harrington, D. (2004). Studies to determine the critical control points in pork slaughter hazard analysis and critical control point systems. International Journal of Food Microbiology. 2004; 90:331-339. DOI:10.1016/s0168-1605(03)00333-7.

Peña-Meléndez, M, Perry, JJ, Yousef, AE. Changes in Thermal Resistance of Three Salmonella Serovars in Response to Osmotic Shock and Adaptation at Water Activities Reduced by Different Humectants. Journal of Food Protection. 2014; 77(6):914-918. DOI:10.4315/0362-028X.

PETROBRAS. Comissão de Assistência Técnica Petrobras. Gás Liquefeito de Petróleo: Informações Técnicas. Versão 1.2. Available from: <http://sites.petrobras.com.br/minisite/a ssistenciatecnica/public/downloads/man ual-tecnico-gas-liquefeito-petrobrasassistencia-tecnica-petrobras.pdf $>$. Acesso em: 04 ago. 2018.

Rahkio, M, Korkeala, H, Sippola, I, Peltonen, M. Effect of pre-scalding brushing on contamination level of pork carcasses during the slaughtering process. Meat Science. 1992; 32: 173-
183.

DOI:10.1016/03091740(92)90104-C.

Simitzis, P.E., Symeon, G.K., Charismiadou, M.A., Bizelis, J.A., Deligeorgis, S.G. The effects of dietary oregano oil supplementation on pig meat characteristics. Meat Science, 2010; 84 (4): 670-676.

DOI:10.1016/j.meatsci.2009.11.001.

Spescha, C, Stephan, R, Zweifel, C. Microbiological contamination of pig carcasses at different stages of slaughter in two European Union-approved abattoirs. Journal of Food Protection, 2006; 69:2568-2575. DOI:10.4315/0362-028X-69.11.2568.

Turner, C. The thermal inactivation of $\mathrm{E}$. coli in straw and pig manure. Bioresource Technology. 2002; 84:5761. DOI:10.1016/S09608524(02)00008-1.

USDA. United States Department of Agriculture. Foreign Agricultural Service. Livestock and Poultry: World Markets and trade. Available from: $<$ https://apps.fas.usda.gov/psdonline/cir culars/livestock_poultry.pdf>. 2020.

Yu, S-L, Bolton, D, Laubach, C, Kline, P, Oser, A, Palumbo, S. A. Effect of deharing operations on microbiological quality of swine carcasses. Journal of Food Protection. 1999; 62: 1478-1481. DOI:10.4315/0362-028x-62.12.1478. 